\title{
THE EFFECT OF PERORAL ADMINISTRATION OF LACTOBACILLUS FERMENTUM CULTURE ON DAIRY COWS HEALTH INDICES
}

\author{
Laima Liepa, Māra Viduža \\ Clinical Institute, Faculty of Veterinary Medicine, \\ Latvian University of Life Sciences and Technologies \\ Helmana 8, Jelgava, LV-3004, Latvia
}

Received 23 October 2017; Received in revised form 2 February 2018; Accepted 3 March 2018

\begin{abstract}
The culture of Lactobacillus fermentum was isolated from the biogas substrate. The aim was to evaluate the efficiency of perorally applied L. fermentum additive to prevent metabolic diseases in the early lactation period of dairy cows. The experiment was performed in the early lactation group of a herd with 240 cows. The control and experimental group each consisted of 10 clinically healthy cows with normal concentration of $\beta$-hydroxybutyrate and glucose. On day 1-5 (D1-D5), the experimental cows received orally $150 \mathrm{ml}$ of $L$. fermentum product of $8.1 \times 10^{5} \mathrm{CFU} / \mathrm{ml}$. On D1, D2, D5 and D20, the rumen fluid samples were collected from all animals in both groups with an oral-ruminal probe once per day for detection of $\mathrm{pH}$ and concentration of volatile fatty acids, on D1, D5 and D20 - blood samples for biochemical analyses. The data were analyzed using Microsoft Excel. Results: Significant changes were observed in the concentration of the liver enzymes AST and GGT. On D1, in the experimental animals AST concentration 100.5 $\pm 14.0 \mathrm{IU} / \mathrm{L}$ was higher than in control cows $-51.4 \pm 5.7$ IU/L $(\mathrm{p}<0.05)$. On D20, AST was reduced significantly only in experimental cows. On D1, GGT concentration $31.5 \pm 6.91$ IU/L was higher $(p<0.05)$ in experimental animals than in control cows $-13.6 \pm 1.53 \mathrm{IU} / \mathrm{L}$, but on D5, GGT concentration in experimental animals was reduced to $18.4 \pm 6.41 \mathrm{IU} / \mathrm{L}(\mathrm{p}<0.05)$, and remained until D20. Conclusion: L. fermentum culture administered orally for five days improved the blood liver enzymes in cows, and the effect lasted for two weeks.
\end{abstract}

Key words: cows, ketosis, acidosis, Lactobacillus fermentum

\section{INTRODUCTION}

Animals from high productive dairy herds in the early lactation period postpartum are subjected to a risk of falling ill with metabolic diseases, especially ketosis I, caused by negative energy balance, or with a subacute ruminal acidosis (SARA) caused by consumption of excessive amount of easily digestible carbohydrates due to management, feeding problems or heat stress (1). The most important symptoms of ketosis 1 are associated with elevated beta-hydroxybutyrate concentration in the blood above $1.2 \mathrm{mmol} / \mathrm{L}$, reduced milk

Corresponding author: Prof. Laima Liepa, $\mathrm{PhD}$

E-mail address: Laima.Liepa@1lu.lv

Present address: Clinical Institute, Faculty of Veterinary Medicine, Latvian University of Life Sciences and Technologies, Helmana 8,

Jelgava, LV-3004, Latvia

Phone: +371 63021972; Fax: +37163027344

Copyright: (C) 2018 Liepa L. This is an open-access article published under the terms of the Creative Commons Attribution License which permits unrestricted use, distribution, and reproduction in any medium, provided the original author and source are credited.

Competing Interests: The authors have declared that no competing interests exist.

Available Online First: 25 June 2018

Published on: 15 October 2018

https://doi.org/10.2478/macvetrev-2018-0017 yield, increase of milk fat concentration above $5.5 \%$, milk fat to protein ratio above 1.6 , reduced dry matter (DM) consumption and development of many reproductive problems (2). The most important clinical findings of SARA problem are: periodically reduced rumen fluid $\mathrm{pH}$ of at least 180 min/day below 5.8 (3), milk fat content below $3 \%$, milk fat to protein ratio below 1.1 (4), or decrease of milk fat and true protein from 37 to $34 \mathrm{~g} / \mathrm{kg}$ and 29 to $28 \mathrm{~g} / \mathrm{kg}$, respectively, reduced DM consumption, lowered milk productivity and, in a longer period of time, development of metabolic disturbances in the liver, reduced reproduction performance and inflammation processes like lameness and elevated number of somatic cell count $(5,6)$.

In order to improve the gastrointestinal tract activity and related metabolic processes, many feed additives have been investigated such as inorganic chemical compounds (for example, propylene glycol, sodium hydrogen carbonate), vitamins (niacin, choline), biological additives, for example antibiotics (monensin) and probiotics (bacteria, yeasts) (2). Probiotics or direct-fed microbials (DFM) are live 
microbial feed supplements which beneficially affect the host animal microbial balance, while for adult ruminants they improve fiber digestion by rumen microorganisms (7). They have positive effects on various digestive processes such as cellulolysis and the synthesis of microbial proteins (8). Probiotics can reduce diseases of ruminants related to the disturbance of the rumen content $\mathrm{pH}$ (for example, acidosis) and stabilize ruminal $\mathrm{pH}$ by modulating rumen microbes (9). The DFM, including bacteria, yeast and fungi use during the early lactation may be the best choice since cows are in negative energy balance with high fermentable carbohydrates, and it is associated with SARA (10).

Lactobacillus fermentum has been identified as a probiotic, Gram-positive bacteria with an antioxidative and antimicrobial activity. It can be a normal inhabitant of the gastrointestinal tract. Lactobacillus spp. sustain lactic acids at a more constant level than Streptococcus bovis (8). The strain of human origin L. fermentum ME-3 has a positive influence on the microbiota of the gut: this strain has the capability to suppress mainly Gram-negative bacteria such as Salmonella spp., Enterococcus spp. and Staphylococcus aureus (11). In scientific literature, no information was found about a supplementary dosage of $L$. fermentum in feeding of ruminants, whereas there was information about dosages of other related Lactobacillus species. Application of L. plantarum strain 115 and L. rhamnosus strain 32 to the rumen at the rate of $1 \times 10^{11} \mathrm{CFU} / \mathrm{sheep} /$ day was effective in stabilizing the rumen $\mathrm{pH}$ and preventing acidosis artificially induced by three days of concentrate challenge (12), but $L$. plantarum strain PCA236 supplementation in feed reduced Clostridium spp. load in the faeces of goats (13). Cattle fed L. aciodophilus strain LA747 from $1.2 \times 10^{9} \mathrm{CFU} /$ cow/day to $5 \times 10^{11} \mathrm{CFU} / \mathrm{cow} /$ day had better feed efficiencies and weight gain, as well as higher milk productivity $(10,14)$. Another study showed that the period of time of the ruminal $\mathrm{pH}$ below 6 was reduced in dairy cows fed $L$. acidophilus $5 \times 10^{8} \mathrm{CFU} / \mathrm{cow} /$ day. However, supplementation of DFM as a tool for manipulating ruminal microbial fermentation processes has not always been effective and has showed various results. Results depend on many factors like feed composition, feeding regime, DFM doses and duration, environmental circumstances, cows' lactation period and age $(14,15)$. The previous studies have proved that $L$. fermentum strain RC-14 has a therapeutic effect on human urinary tract infection and vaginal candidiasis (16). Several strains of probiotics have an altering action on the gut permeability and cytokines secretion,and can potentially treat or prevent liver diseases (17). Regular consumption of probiotics has a repairing effect on the mucosal barrier of the gastrointestinal tract and apoptosis prevention provided by short chain acids, as well as on a lowered ammonia absorption due to reduced luminal permeability. $L$. fermentum in different combinations with other probiotics, L. reuteri, L. rhamnosus, L. plantarum or $B$. catenulatum, have a significantly modulated extent of liver failure, reduced concentration of liver enzyme ALT, cytokine TNF-alfa and endotoxemia, lowered bacterial translocation in rats $(3,18)$.

Published data on investigations of $L$. fermentum action on the health indices and productivity of dairy cows was not found. Ketosis and subacute ruminal acidosis (SARA) are common metabolic and management problems of high productive cows in many dairy herds in Latvia. The aim of the authors of the present experiment was to evaluate the efficiency of perorally applied $L$. fermentum additive to prevent metabolic disorders and control health indices in the early lactation group of dairy cows.

\section{MATERIAL AND METHODS}

The experiment was performed in the early lactation group of a 240 Holstein dairy cows herd affected by ketosis I and SARA in 2016. The ketosis developed mostly during a 50-day period after calving and was associated with management stress in the peripartum period: parturition, regrouping after calving, changes in feed composition and intake. During the period of lactation increase, the energy feed amount of the ration is calculated according to the milk yield. SARA problems develop gradually in cows in the early lactation period, reaching the maximum incidence in the mid-lactation period of $90-150$ days.

All experimental procedures with animals were performed in accordance with the guidelines of the Directive 2010/63/EU of the European Parliament and of the Council from 22 September 2010 on the protection of animals used for scientific purposes and were approved by the Ethics Council for Animal Protection at the Latvian University of Life Sciences and Technologies, Jelgava, Latvia.

Before the clinical experiments with cows, the L. fermentum culture was isolated from a Biogas reactor substance at the accredited Laboratory for Microorganism Cultures at the Faculty of Biology of the University of Latvia. The L. fermentum culture was cultivated in a liquid malt medium in thermostat at $37.7^{\circ} \mathrm{C}$, and transferred onto a fresh 
medium every 2 weeks. The colony forming units (CFU) were determined at a various age of L. fermentum growing: at the age of 14 and 21 days there were $8.1 \times 10^{5} \mathrm{CFU} / \mathrm{ml}$ and $8.0 \times 10^{5} \mathrm{CFU} / \mathrm{ml}$, respectively. In the experiments with animals, L. fermentum was cultivated in identical circumstances in a laboratory situated close to the experimental farm. Fourteen days grown L. fermentum cultures were used which contained $8.1 \times 10^{5} \mathrm{CFU} / \mathrm{ml}$. The effective dose of $L$. fermentum was obtained in preliminary experiments with cows.

Control (C) and Experimental (E) group each consisted of 10 dairy cows ( 7 in the first, 11 - the second and 2 - the third lactation), $16-62$ days in lactation with equal feeding, holding circumstances and milking regime, with milk fat to protein ratio 0.95-1.13, and milk fat content below 3.5\%. All cows from the high productive group received ad libitum total mixed feed (TMF) which contained corn silage (28\%), legume - grass silage (52\%), flattened wheat grain and oilseed rape cakes (about $20 \%$ ), unchoped hay and straw $1.0-1.5 \mathrm{~kg} / \mathrm{cow}$.

At the beginning of the investigation on day 1-5 (D1-D5), the E cows received orally $150 \mathrm{ml}$ of L. fermentum product of $8.1 \times 10^{5} \mathrm{CFU} / \mathrm{ml}$ diluted in water, but the $\mathrm{C}$ cows received orally $150 \mathrm{ml}$ of drinking water at 10.00 A.M., which was four hours after receiving fresh TMF. The rumen fluid samples of 250-500 ml were collected from all animals in both groups with a metallic oral-ruminal probe once per day on D1, D2 and D5 before receiving L. fermentum product in E group or drinking water in C group, and on D20 without L. fermentum product or drinking water, for detection of $\mathrm{pH}$ and concentration of VFA: acetic, lactic and butyric acids. All samples had been frozen and held in a refrigerator at $-20{ }^{\circ} \mathrm{C}$ temperature. In the Scientific Laboratory for Agronomic Analyses at the Latvian University of Life Sciences and Technologies, the state approved silage testing method was used for detection of the concentrations of VFA in rumen fluid: $50 \mathrm{~g}$ of frozen rumen content was thawed in a flask and supplemented with $500 \mathrm{ml}$ of distilled water, shaken up and filtrated. De-sugaring of the filtrate was performed by adding $10 \mathrm{ml}$ of $10 \% \mathrm{CuSO}_{4}$ and $20 \mathrm{ml}$ of $10 \% \mathrm{CaO}$ to $200 \mathrm{ml}$ of filtrate; in one hour the sugar sediments were removed by filtration. $5 \mathrm{ml}$ of $50 \% \mathrm{H}_{2} \mathrm{SO}_{4}$ were added to $200 \mathrm{ml}$ of the de-sugared filtrate, after which it was shaken, with a condenser connected and heated. After 20 minutes of boiling, $100 \mathrm{ml}$ of $\mathrm{CH}_{3} \mathrm{COOH}$ distillate was collected in a flask, after 10 minutes $50 \mathrm{ml}$ of $\mathrm{C}_{4} \mathrm{H}_{8} \mathrm{O}_{2}$ distillate was collected. After that, the distillation was interrupted and $55 \mathrm{ml}$ of $\mathrm{K}_{2} \mathrm{Cr}_{2} \mathrm{O}_{7}$ and $100 \mathrm{ml}$ of $\mathrm{H}_{2} \mathrm{O}$ were added to the solution. Then, it was boiled for 10 minutes again, and $50 \mathrm{ml}$ of $\mathrm{C}_{3} \mathrm{H}_{6} \mathrm{O}_{3}$ was collected in a flask. Each distillate was titrated with $0.1 \mathrm{n} \mathrm{NaOH}$ in the presence of phenolphthalein automatically with Titronic 96 and the amounts of VFA in the rumen fluid were calculated.

The blood samples for haematological and biochemical analyses were collected from all experimental and control animals on D1, D5 and D20. Milk samples for detection of protein and fat percentage were collected and the ratio of milk fat and protein was calculated in the experimental and control groups on D1, D5 and D 30. On D1, blood and milk samples were taken before starting to give L. fermentum culture or drinking water. The blood samples were taken by venipuncture from $v$. coccigea with a G18 needle in a vacuum tube. The blood biochemical and haematological analyses were performed by using the following equipment: Mindray B 380, Exigo EOS VET and using an optical microscope Nicon Eclipse 80i (top ocular CFI 10x22, samples were investigated in the oil immersion at 100x magnification). The whole milk biochemical analyses for determination of milk fat and protein content was performed in the EU accredited Dairy Laboratory Ltd. using the following equipment: CombiFoss FT 6000 (method ISO 9622/ IDF 141). The data were statistically analysed using Microsoft Excel. All parameters of haematological and biochemical analyses of blood, rumen fluid and milk samples were checked for normality and expressed as means \pm SEM. Differences between cows' blood, rumen fluid and milk sampling times were analysed by a two-tailed pair Student's $t$-test. A significance level of $\mathrm{p}<0.05$ was accepted throughout the study.

\section{RESULTS}

At the beginning of the investigation, the average milk yield, milk fat amount, and milk fat to protein ratio did not differ significantly. On D1 in C and E animals, the average milk yield was $24.0 \pm 2.72 \mathrm{~kg} /$ day and $36.39 \pm 2.30 \mathrm{~kg} /$ day, the average fat amount was $3.29 \pm 0.2 \%$ and $3.27 \pm 0.38 \%$, but the average fat to protein ratio was $1.09 \pm 0.08$ and $1.29 \pm 0.18$, respectively. During the experiment on D1 - D5, alterations of the above mentioned parameters in both groups did not differ significantly. While on D30, the average milk yield in $\mathrm{C}$ and $\mathrm{E}$ group was $34.47 \pm 2.03 \mathrm{~kg} /$ day and $33.70 \pm 1.95 \mathrm{~kg} /$ day $(\mathrm{p}>0.05)$, respectively; the milk fat amount was $3.00 \pm 0.24 \%$ and $0.20 \%(p>0.05)$, respectively. Only the milk fat to protein ratio during D1 - D30 was reduced significantly $(\mathrm{p}<0.05)$ in both groups - in E group it was $0.97 \pm 0.08$, while in C group $0.96 \pm 0.04$. 
The only significant difference $(\mathrm{p}<0.05)$ of the average milk protein amount was already on D1 between the $\mathrm{E}$ and $\mathrm{C}$ group of cows $2.77 \pm 0.10 \%$ and $3.24 \pm 0.12 \%$, respectively (Fig. 1). In E cows, a significant improvement of the increase of average protein amount was observed from D1 to D30, $2.77 \pm 0.10 \%$ and $3.11 \pm 0.04 \%(\mathrm{p}<0.05)$, respectively. At the same time, the alterations of the protein content of $\mathrm{C}$ cows were insignificant, i.e. $3.52 \pm 0.24 \%$ on D1 and $3.11 \pm 0.20 \%$ on D30.

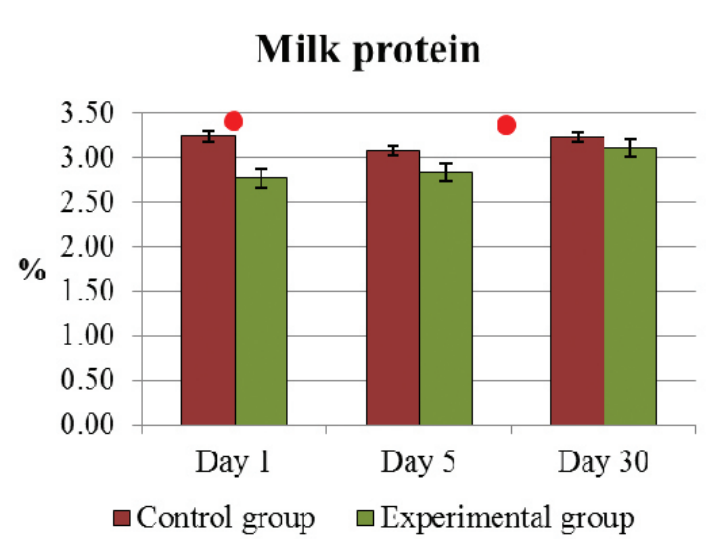

Figure 1. Milk protein percentage (mean $\pm S E M)$ in E and C group of cows during D1 to D30. - Significant $(\mathrm{p}<0.05)$ difference in the results: 1$)$ on D1 - between $\mathrm{E}$ and C group; 2) in D1- D30 period - only in E group

Starting the experiment on D1, the rumen content $\mathrm{pH}$ was similar in $\mathrm{C}$ and $\mathrm{E}$ groups $6.62 \pm 0.15$ and $6.47 \pm 0.14$, respectively. However on D5, the level of ruminal fluid $\mathrm{pH}$ was significantly reduced $(\mathrm{p}<0.05)$ in C group 6.19 \pm 0.12 , but in E group the decrease did not differ significantly $6.25 \pm 0.11$ (Fig. 2).

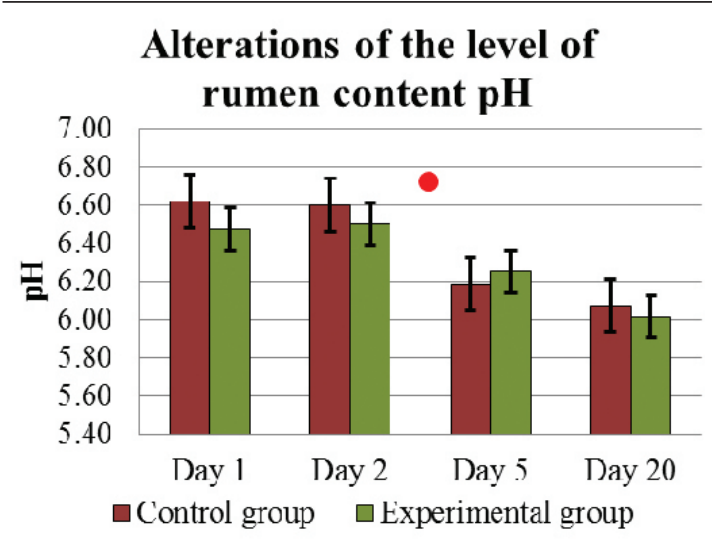

Figure 2. Alterations of the level of rumen content $\mathrm{pH}$ (mean \pm SEM) in E and $\mathrm{C}$ group of cows during D1 to D20. $\bullet$ Significant $(\mathrm{p}<0.05)$ difference in the results: in D1 - D5 period - in C group
At the beginning of the investigation on D1, in $\mathrm{E}$ and $\mathrm{C}$ cows no significant differences were found in any of the analyzed VFA of ruminal fluid. The average concentration of acetic acid in the rumen content during D1 to D20 had altered similarly and increased significantly $(\mathrm{p}<0.05)$ in both animal groups: on D1, it was $0.48 \pm 0.02 \%$ in $\mathrm{C}$ group and $0.49 \pm 0.02 \%$ in $\mathrm{E}$ group, but on D20, it reached $0.55 \pm 0.03 \%$ and $0.55 \pm 0.01 \%$, respectively (Fig. 3).

\section{The concentration alterations of acetic acid in rumen content}

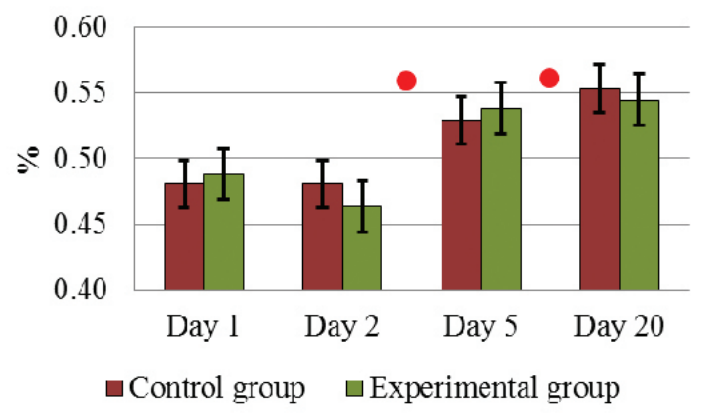

Figure 3. The concentration (mean $\pm \mathrm{SEM}$ ) alterations of acetic acid in the rumen content in $\mathrm{E}$ and $\mathrm{C}$ group of cows during D1 to D20. • Significant $(\mathrm{p}<0.05)$ difference in the results: 1) In D2-D5 period - in E group; 2) in D5 D20 period - in $\mathrm{E}$ and $\mathrm{C}$ groups

Under the influence of $L$. fermentum on D5, the concentration of lactic acid and butyric acid had increased the most $0.14 \pm 0.01 \%$ and $0.27 \pm 0.01 \%$, respectively. These results on D5, in E cows were significantly higher $(\mathrm{p}<0.05)$ than in $\mathrm{C}$ group of cows $0.11 \pm 0.01 \%$ and $0.23 \pm 0.02 \%$, respectively (Fig. 4 and. 5). On completion of the feeding L. fermentum, the concentration of both VFA had decreased, and on D20 it was $0.11 \pm 0.01 \%$ and $0.25 \pm 0.02 \%$, respectively, similar to that in C animals. However, during experiment D5 - D20, the alterations in the concentration of lactic acid in E cows were not significant.

The concentration of blood serum lactate on D1 was above the physiologically normal value $(0.6-$ $1.4 \mathrm{mmol} / \mathrm{L}$ ) in both groups: $2.67 \pm 0.23 \mathrm{mmol} / \mathrm{L}$ in $\mathrm{C}$ and $3.02 \pm 0.13 \mathrm{mmol} / \mathrm{L}$ in E (Fig. 6). On D5, the level of lactate in both groups had significantly $(\mathrm{p}<0.05)$ decreased to the normal level, that is, in $\mathrm{C}$ animals to $1.14 \pm 0.08 \mathrm{mmol} / \mathrm{L}$, in E $1.19 \pm 0.13 \mathrm{mmol} / \mathrm{L}$. At the end of the experiment, serum lactate remained at a similar concentration of $1.0 \pm 0.1 \mathrm{mmol} / \mathrm{L}$ in $\mathrm{C}$ group animals, but in E cows, it tended to increase to $1.41 \pm 0.16 \mathrm{mmol} / \mathrm{L}(\mathrm{p}>0.05)$. 


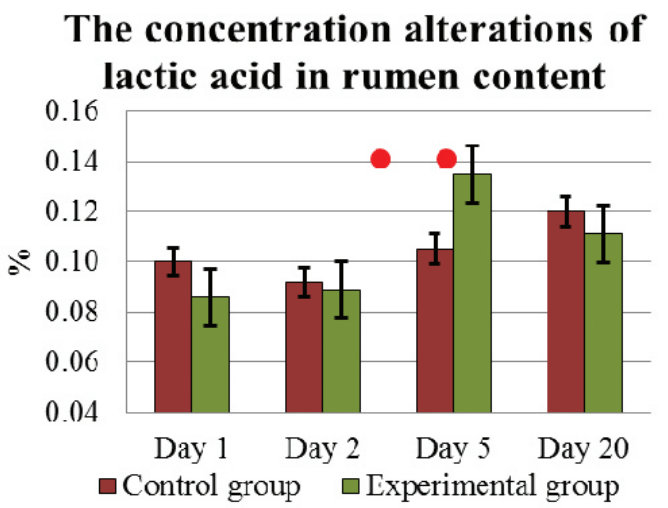

Figure 4. The concentration (mean $\pm \mathrm{SEM}$ ) alterations of lactic acid in the rumen content in $\mathrm{E}$ and $\mathrm{C}$ group of cows during D1 to D20. • Significant $(\mathrm{p}<0.05)$ difference in the results: 1) In D1-D5 period - in E group; 2) on D5 between $\mathrm{E}$ and $\mathrm{C}$ group

\section{The concentration alterations of butyric acid in rumen content}

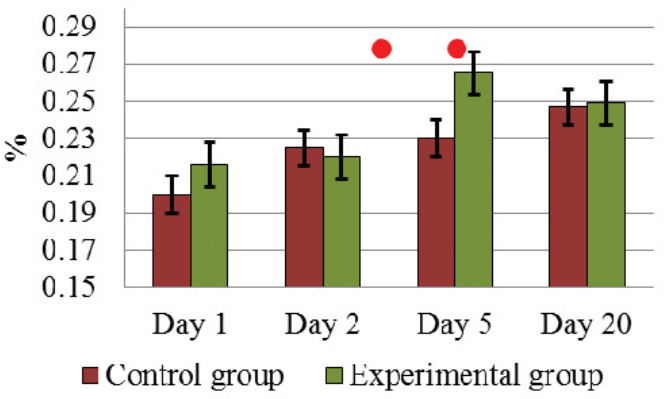

Figure 5. The concentration (mean \pm SEM) alterations of butyric acid in the rumen content in $\mathrm{E}$ and $\mathrm{C}$ group of cows during D1 to D20. - Significant $(p<0.05)$ difference in the results: 1) In D1-D5 period - in E group; 2) on D5 - between E and C group

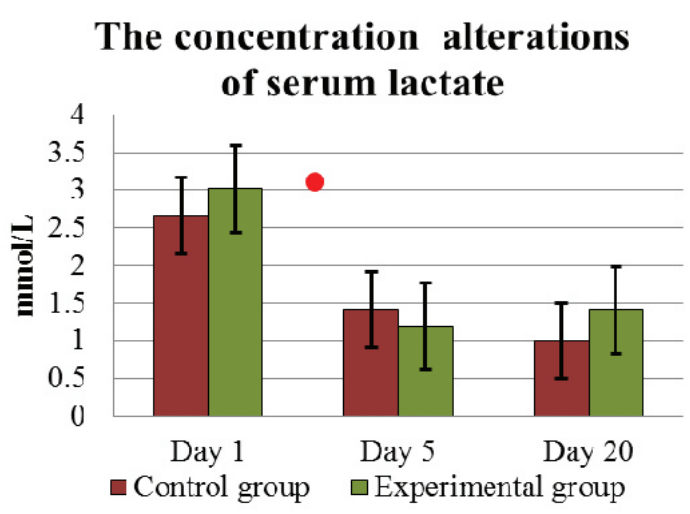

Figure 6. The concentration (mean \pm SEM) alterations of serum lactate in $\mathrm{E}$ and $\mathrm{C}$ group of cows during D1 to D20. - Significant difference $(p<0.05)$ in the results: in D1 - D5 period - in E and C groups
The effect of L. fermentum culture on the liver functions and hepatocytes are characterized by the concentration alterations of glucose, aspartate aminotransferase (AST) and gamma-glutamyl transferase (GGT) activity in blood. Throughout the experiment, the concentration of serum glucose was within the physiologically normal value $(2.2-$ $3.3 \mathrm{mmol} / \mathrm{L}$ ), both in $\mathrm{C}$ and $\mathrm{E}$ group (Fig. 7). The average concentration of glucose in the serum on D1 was $2.89 \pm 0.1 \mathrm{mmol} / \mathrm{L}$, but on the last D5 of feeding lactic acid bacteria, it increased significantly $(\mathrm{p}<0.05)$ up to $3.35 \pm 0.13 \mathrm{mmol} / \mathrm{L}$. Such level of glucose $3.15 \pm 0.10 \mathrm{mmol} / \mathrm{L}$ remained until D20. In $\mathrm{C}$ group, the alterations of the glucose level were similar during the investigation.

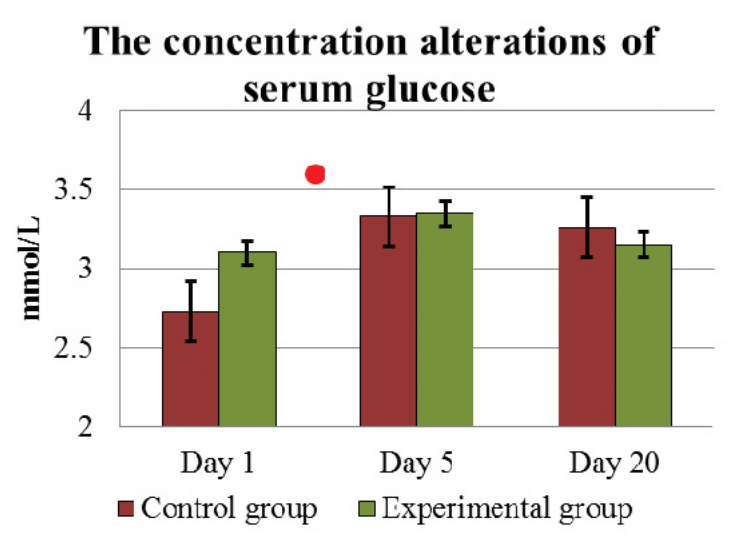

Figure 7. The concentration (mean \pm SEM) alterations of serum glucose in $\mathrm{E}$ and $\mathrm{C}$ group of cows during D1 to D20. - Significant difference $(\mathrm{p}<0.05)$ in the results: in $\mathrm{D} 1$ - D5 period - in $\mathrm{E}$ and $\mathrm{C}$ groups

Determining the AST concentration in the blood serum, all parameters of $\mathrm{E}$ and $\mathrm{C}$ group cows during D1 - D20 period were within the physiologically normal value $(42-115$ IU/L). In E group cows, the average AST activity before the L. fermentum culture intake on D1 was $100.5 \pm 14.01$ IU/L, but in $\mathrm{C}$ group cows it was significantly $(\mathrm{p}<0.005)$ lower $51.4 \pm 5.72 \mathrm{IU} / \mathrm{L}$ (Fig. 8). However, under the influence of intake of L. fermentum, AST concentration in E cows' blood serum decreased significantly $(\mathrm{p}<0.05)$, and on D5 it was $60.3 \pm 6.09$ IU/L. This effect continued with concentration decreasing significantly $(\mathrm{p}<0.05)$ until on D20 AST concentration was $40.6 \pm 5.07$ IU/L. Although in $\mathrm{C}$ group cows, the blood serum AST activity elevated on D5 and on D20 it was $66.0 \pm 11.73 \mathrm{IU} / \mathrm{L}$, its activity had not been higher than in $\mathrm{E}$ animals ( $>0.05$ ). 


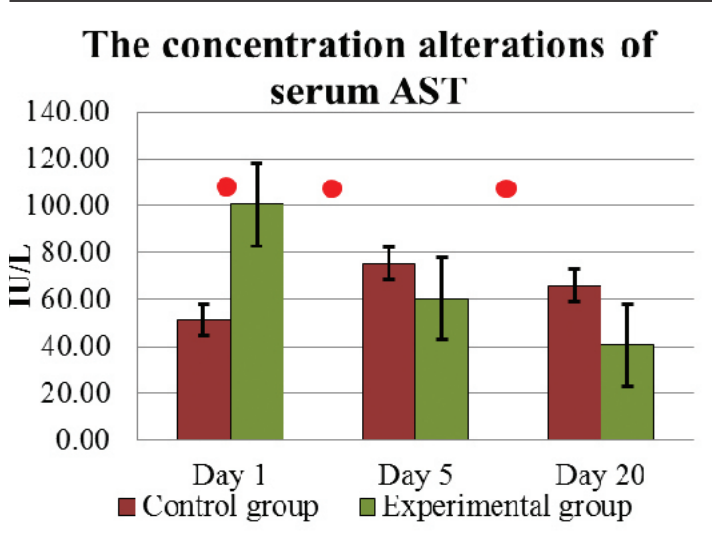

Figure 8. The concentration (mean \pm SEM) alterations of serum AST in E and C group of cows during D1 to D20. - Significant $(p<0.05)$ difference in the results: 1$)$ on D1 - between E and C group; 2) in D1- D5 period AST reduced in E group, but increased - in C group; 3) in D5-D20 period - in E group

Serum GGT concentration in cows used in the present investigation had been within the physiologically normal range (4-30 IU/L) throughout the experiment (Fig. 9). In E group cows, serum GGT activity, similar to that of AST concentration, on D1 was significantly $(p<0.05)$ higher $31.5 \pm 6.91 \mathrm{IU} / \mathrm{L}$ than in $\mathrm{C}$ group. As a result of the influence of L. fermentum, on D5 the average concentration of GGT also decreased insignificantly ( $p>0.05$ ) to $17.78 \pm 3.28$ $\mathrm{IU} / \mathrm{L}$, and the obtained effect $18.4 \pm 6.41 \mathrm{IU} / \mathrm{L}$ remained up to D20. However, in $\mathrm{C}$ group cows, the level of GGT in serum was not significantly $(p>0.05)$ elevated during the first five days, $13.62 \pm 1.53 \mathrm{IU} / \mathrm{L}$ on D1, 19.63 $\pm 2.92 \mathrm{IU} / \mathrm{L}$ on D5, and had remained at a similar level $17.98 \pm 4.11 \mathrm{IU} / \mathrm{L}$ to D20.

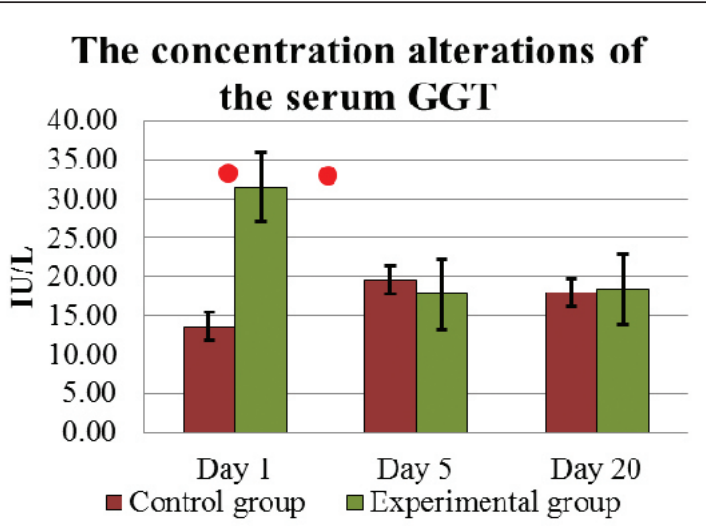

Figure 9. The concentration (mean \pm SEM) alterations of the serum GGT in E and C group of cows during D1 to D20. - Significant $(\mathrm{p}<0.05)$ difference in the results: 1) on D1 - between E and C group; 2) in D1- D5 period - in E group

\section{DISCUSSION}

The only available method for determination of VFA in this research was determination of the percentage of organic acids in feed. Unfortunately, it was impossible to detect by this method the concentration of propionic acid, resulting in a lack of opportunity to establish a significant parameter characterizing the rumen VFA proportion - acetic acid to propionic acid ratio. Taking into consideration that during the storage of samples alteration of VFA concentration is possible, time and conditions of collection and freezing of ruminal samples had been identical. Also, an identical period of time from the sample thawing to the start of analysis was observed. Since analysis of the amount of VFA in ruminal fluid according to the above mentioned method were not found in scientific literature, the obtained results of the present experiment can only be used to evaluate a relative alteration of acetic acid, lactic acid and butyric acid formation during D1 - D20 period, not for analysis of quantitative concentration in experimental and control groups.

In lactating cows, during the postpartum period, perorally administered $150 \mathrm{ml}$ of L. fermentum culture dose of $8.1 \times 10^{5} \mathrm{CFU} / \mathrm{ml}$ had been effective to cause a significant decrease of liver enzymes AST and GGT in the serum, which shows evidence of a decrease of hepatocytes damage often found postpartum. During the experiment, energy deficiency was not established in the metabolic processes of animals, which served as evidence of the concentration alterations of serum glycose and beta-oxybutyric acid within the norm on D1 to D20. In E group, a decrease of the liver enzymes activity can be explained by alterations of the rumen content VFA during the first four days when a significant $(p<0.05)$ elevation of the concentration of butyric acid and lactic acid percentage was determined. Alterations of the concentration of lactic acid could be associated with the direct activity of Lactobacillus culture in the rumen that produces D-lactic acid (19). In the present experiment, in C group cows, the decrease of ruminal fluid $\mathrm{pH}$ on D1 - D5 was significant $(\mathrm{p}<0.05)$, and it negatively $(\mathrm{r}=-0.63)$ correlated with lactic acid and butyric acid $(\mathrm{r}=-0.72)$ concentration. It means that during that time, lactic and butyric acid producing bacteria in the rumen microflora developed more. Since in E group, during a period of four days, the $\mathrm{pH}$ decrease of rumen content was not significant $(\mathrm{p}>0.05)$, it had a weak correlation $(r=-0.37)$ with lactic acid concentration, but there was a strong negative correlation with butyric acid $(r=-0.798)$ concentration. 
In E group, only on $\mathrm{D} 2$ did the ruminal $\mathrm{pH}$ have a strong negative correlation $(r=-0.92)$ with acetic acid concentration, while on D5 this correlation was moderate $(\mathrm{r}=-0.40)$. In $\mathrm{C}$ group, on D1-D5 a significant correlation between ruminal fluid $\mathrm{pH}$ and acetic acid concentration was not obtained. Overall, these results indicate a stabilizing efficacy of L. fermentum on the ruminal $\mathrm{pH}$, because probiotics have a positive balancing influence on the microbiota by increasing the amount of cellulolytic bacteria and acetic fermentation in the rumen (20), while in the present experiment, greater influence on butyric acid and lactic acid production was observed. D- and L-form of lactic acid (dextrorotatory and levorotatory lactic acid) absorb easily through the epithelium of rumen and get into the bloodstream. If the total concentration of lactic acid increases in the blood, then this is L-lactic acid, which is more readily secreted through the kidneys. The more D-lactic acid is formed, as it could be in the present experiment, the more L-lactic acid is retained in the blood (21). L-lactate is quickly metabolized in the liver by L-lactic dehydrogenase to pyruvate, which will be turned into glucose through gluconeogenesis (21). In our experiment, the serum lactate concentration of E cows could be higher with D-lactate because L. fermentum additives produced it in the rumen content. In the period between D1-D5, the serum lactate concentration tended to decrease more in the animal group which was fed L. fermentum (Fig. 5). This could indicate that the process of lactic acid metabolism in liver had occurred more rapidly, and a larger amount of pyruvate had been formed in the liver from L-lactate than in $\mathrm{C}$ group animals. Possibly, by increasing the metabolic energy amount in the liver, hepatocyte damage was decreased, and the concentration of liver enzymes in the serum had decreased. In C cows, in the period between D1D5, a similarly significant $(\mathrm{p}<0.05)$ reduction of the serum lactate concentration was observed, but quantitatively less than in E group. Theoretically, $\mathrm{C}$ cows serum lactate could contain less D-lactate than E animals. In such a situation, relatively less L-lactate could be retained in the blood and less amount of pyruvate could be formed in the liver (21). In both groups, in the D5-D20 period the changes in the serum lactate concentration were not significant ( $p>0.05)$, but in E group there was a tendency for it to increase (Fig. 5). It means that the serum lactate reducing effect lasted only during the L. fermentum feeding period. An additional positive effect of L. fermentum on the content of ruminal microbiota is possible, as some Lactobacillus species contain proteinase that is capable to split polypeptides of the dangerous bacteria in the gastro-intestinal tract and diminish inflammatory processes in the rumen epithelium (22). To prove the effect of L. fermentum feed additives, further studies are necessary.

In E group, an increased concentration of butyric acid within the physiologically normal value $(12-18 \%$ of VFA) can facilitate the rumen villi prolongation and improve the proliferation of gastro-intestinal cells (23). Butyrate, when used per os, decreases the concentration of postprandial plasma insulin and glucose at a metabolic level; therefore, butyric acid can decrease the incidence of metabolic diseases in cows (24), including hepatic lipidosis postpartum. In our experiment, the higher concentration of butyric acid in the rumen fluid of $\mathrm{E}$ cows can induce improvement of cows' metabolism without significant increase in the serum glucoses level (compared with $\mathrm{C}$ cows) and reduce the activity of serum AST and GGT, and consequently reduce the damage of hepatocytes.

\section{CONCLUSION}

Feeding L. fermentum culture $150 \mathrm{ml}$ dose of $8.1 \times 10^{5} \mathrm{CFU} / \mathrm{ml}$ in lactating cows in postpartum period has a stabilizing effect on the rumen content $\mathrm{pH}$ and stimulates formation of VFA in the rumen, in particular the ones of lactic acid. It reduces the damage of liver cells and decreases serum lactate concentration, thus preventing metabolic diseases in the early lactation period. Determination method of the amount of organic acids in feed can be used to evaluate a relative alteration of rumen VFA concentration, provided that the period of time and conditions of collection and freezing of rumen's content samples are identical. Also, an identical period of time from the sample thawing to the start of analysis is to be observed.

\section{CONFLICT OF INTEREST STATEMENT}

The authors declared that they have no potential conflict of interest with respect to the authorship and/or publication of this article.

\section{ACKNOWLEDGMENT}

This study was supported by a grant from the State Research Project (AgroBioRes) No. 2014.10-4/VPP-7/5. 


\section{REFERENCES}

1. Gantner, V., Kuterovac, K., Potočnik, K. (2016). Effect of heat stress on metabolic disorders prevalence risk and milk production in Holstein cows in Croatia. Ann. Anim. Sci., 16 (2): 451-461. https://doi.org/10.1515/aoas-2015-0097

2. Fleming, S.A. (2015). Bovine metabolic disorders. In: Smith B.P. (Eds.), Large animal internal medicine (pp. 1252-1258). St. Louis, Missouri: Mosby, Elsevier Inc.

3. Wang, D.S., Zhang, R.Y., Zhu, W.Y., Mao, S.Y. (2013). Effects of subacute ruminal acidosis challenges on fermentation and biogenic amines in the rumen of dairy cows. Livestock Science 155(2-3): 262-272.

https://doi.org/10.1016/j.livsci.2013.05.026

4. Čejna, V., Chládek, G. (2005). The importance of monitoring changes in milk fat to milk protein ratio in holstein cows during lactation. Journal of Central European Agriculture 6(4): 539-546.

5. Muralithas, M., Shakthevale, A., Pushpakumara, P.G.A. (2011). Herd-based diagnosis of subacute ruminal acidosis (SARA) and disease investigation of the lameness at New Zealand dairy farm in Sri Lanka. Proceedings of the 16th International Symposium and 8th Conference on Lameness in Ruminants, Rotorua, New Zealand.

6. Oetzel, G. R., Krause, K. M. (2006). Understanding and preventing subacute ruminal acidosis in dairy herds. Anim. Feed Sci. Technol. 126, 215-236. https://doi.org/10.1016/j.anifeedsci.2005.08.004

7. Fuller R. (1989) Probiotics in man and animals. J. Appl. Bacteriol. 66(5): 365-378.

https://doi.org/10.1111/j.1365-2672.1989.tb05105.x PMid:2666378

8. Uyeno, Y., Shigemori, S., Shimosato, T. (2015). Effect of Probiotics/Prebiotics on Cattle Health and Productivity. Microbes Environ., 30(2):126-132. https://doi.org/10.1264/jsme2.ME14176 PMid:26004794 PMCid:PMC4462921

9. Bajagai,Y.S., Klieve, A.V, Dart. P.J., Waine, L.B. (2016). Probiotics in ruminant Nutrition. In: H.P.S. Makkar (Ed.), FAO Animal production and health paper No. 179 (pp.37-48). Rome: FAO.

10. Kung, L. (2001). Direct-fed microbials for dairy cows and enzymes for lactating dairy cows: New theories and applications. Proceeding of the Pennsylvania State Dairy Cattle Nutrition Workshop (pp. 86-102). Grantville, Pennsylvania State, USA.
11. Mikelsaar, M., Mihkel, Z. (2009). Lactobacillus fermentum ME-3 an antimicrobial and antioxidative probiotic. Microb Ecol Health Dis. 21(1): 1-27. https://doi.org/10.1080/08910600902815561 PMid:19381356 PMCid:PMC2670518

12. Lettat, A., Nozière, P., Silberberg, M., Morgavi, D.P., Berger, C., Martin, C. (2012). Rumen microbial and fermentation characteristics are affected differently by bacterial probiotic supplementation during induced lactic and subacute acidosis in sheep. BMC Microbiology 12(1): 142.

https://doi.org/10.1186/1471-2180-12-142

PMid:22812531 PMCid:PMC3438074

13. Maragkoudakis, P.A., Mountzouris, K.C., Rosu, C., Zoumpopoulou, G., Papadimitriou, K. (2010). Feed supplementation of Lactobacillus plantarum PCA 236 modulates gut microbiota and milk fatty acid composition in dairy goats-a preliminary study. Int. J. Food Microbiol. 141, 109-116. https://doi.org/10.1016/j.ijfoodmicro.2010.03.007 PMid:20356645

14. Yoon, I.K., Stern, M.D. (1995). Influence of directfed microbials on ruminal microbial fermentation and performance of ruminants. Asian-Australas J Anim Sci, 8(6): 533-555. https://doi.org/10.5713/ajas.1995.553

15. Khan, R.U., Naz, S., Dhama, K., Karthik, K., Tiwari, R., Abdelrahman, M.M., Alhidary, I.A., Zahoor, A. (2016). Direct-fed microbial: beneficial applications, modes of action and prospects as a safe tool for enhancing ruminant production and safeguarding health. Int J Pharmacol. 12, 220-231. https://doi.org/10.3923/ijp.2016.220.231

16. Himanshu, K.S., Dipak, D.P., Dushyant, A.S., Vipul, D.P., Girish, K.J., Akil, M.M., Prachi, M.T. (2013). Development of microencapsulation delivery system for long-term preservation of probiotics as biotherapeutics agent. BioMed Research International. [cited 2017 May 03]. https://doi.org/10.1155/2013/620719

17. Xing, H.C., Li, L.J., Xu, K.J., Shen, T., Chen, J.B., Sheng, J.F. et al. (2006). Protective role of supplement with foreign Bifidobacterium and Lactobacillus in experimental hepatic ischemia-reperfusion injury. $\mathrm{J}$ Gastroenterol Hepatol. 21(4): 647-656.

https://doi.org/10.1111/j.1440-1746.2006.04306.x PMid:16677148

18. Adawi, D., Kasravi, F.B., Molin, G., Jeppsson, B. (1997). Effect of Lactobacillus supplementation with and without arginine on liver damage and bacterial translocation in an acute liver injury model in the rat. Hepatology 25(3): 642-647.

https://doi.org/10.1002/hep.510250325 PMid:9049212 
19. Slyter, L.L., Rumsey, T.S. (1991). Effect of coliform bacteria, feed deprivation, and $\mathrm{pH}$ on ruminal D-lactic acid production by steer or continuousculture microbial populations changed from forage to concentrates. Anim Sci. 69(7): 3055-3066.

https://doi.org/10.2527/1991.6973055x

20. Nocek, J.E., Kautz, W.P. (2006). Direct-fed microbial supplementation on ruminal digestion, health, and performance of pre- and postpartum dairy cattle. J Dairy Sci. 89, 260-266.

https://doi.org/10.3168/jds.S0022-0302(06)72090-2

21. Hernández, J., Benedito, J.L., Abuelo, A., Castillo, C. (2014). Ruminal acidosis in feedlot: from aetiology to prevention. The Scientific World Journal. [cited 2017 June 15]

https://doi.org/10.1155/2014/702572

22. Duncan, B. (2013). Probiotics. In: R. R. Watson, V. R. Preedy (Eds.), Bioactive food as dietary interventions for liver and gastrointestinal disease (pp.454-461). Oxford: Elsevier.

PMid:22948527
23. Kanauchi, O., Fujiyama, Y., Mitsuyama, K., Araki, Y., Ishii, T., Nakamura, T., et al. (1999). Increased growth of Bifidobacterium and Eubacterium by germinated barley foodstuff, accompanied by enhanced butyrate production in healthy volunteers. Int J Mol Med. 3(2): 175-179.

https://doi.org/10.3892/ijmm.3.2.175

24. Kato, S., Sato, K., Chida, H., Roh, S., Ohwada, S., Sato, S., Guilloteau, P., Katoh, K. (2011). Effects of Na-butyrate supplementation in milk formula on plasma concentrations of $\mathrm{GH}$ and insulin, and on rumen papilla development in calves. J Endocrinol. 211, 241-248.

https://doi.org/10.1530/JOE-11-0299

PMid:21911440 